\title{
原著
}

\author{
定量的コンピューター断層撮影法（QCT 法）を用いた \\ 下顎骨骨密度と腰椎骨密度との関係
黒須康成*1 稲垣幸司*1 吉成伸夫*1 佐藤連造*1
夫馬大介*1 坂野雅洋*1 杉石 泰*1 岩田武久*1
深田淳一郎*1 高木善 寛*1 野口俊 英*1
内藤 宗 孝 $* 2$ 有地榮一郎*2 田口 明*3
*1愛知学院大学歯学部歯科保存学第三講座
*2愛知学院大学歯学部歯科放射線学講座
*3広島大学医学部・歯学部附属病院口腔再建外科（歯科放射線科）
(2004 年 7 月 17 日受理)

\section{Relationship between the Bone Mineral Density of Mandible \\ by Quantitative Computed Tomography and Lumbar Spine \\ by Dual Energy X-ray Absorptiometry}

\author{
Yasunari Kurosu*1, Koji Inagaki*1, Nobuo Yoshinari*1, Renzo Sato*1, \\ Daisuke Fuma*1, Masahiro Sakano*1, Tai Sugiishi*1, Takehisa Iwata*1, \\ Jun-ichiro Fukada*1, Yoshihiro Takagi*1, Toshihide Noguchi*1, \\ Munetaka Naitoh*2, Eiichiro Ariji*2 and Akira Taguchi*3 \\ Department of ${ }^{* 1}$ Periodontology, and ${ }^{* 2}$ Oral and Maxillofacial Radiology, \\ School of Dentistry, Aichi-Gakuin University \\ ${ }^{* 3}$ Department of Oral and Maxillofacial Radiology, Hiroshima University Hospital \\ Accepted for publication 17 July 2004
}

Osteoporosis is a systemic skeletal disorder characterized by low bone mass. Periodontitis is an inflammation of the supporting tissues of the teeth, usually leading to loss of alveolar bone. The purpose of the present study was to determine the relationship between bone mineral density of mandible (M-BMD) and lumbar spine (L-BMD). Thirty postmenopausal women with periodontitis, who agreed to participate in the study, were divided into 3 groups based on the diagnostic criteria for primary osteoporosis in the Japanese population (2000) ; 10 subjects with normal L-BMD (group N, 60.9 \pm 6.6 years, mean \pm SD), 10 subjects with osteopenia (group O 1, 61.7 \pm 5.6 years) and 10 subjects with osteoporosis (group O 2, 66.6 \pm 7.0 years). M-BMD was measured by quantitative computed tomography and L-BMD was measured by dual

\author{
連絡先：黒須康成 \\ 干 464-8651 名古屋市千種区末盛通 2-11 \\ Yasunari Kurosu \\ Department of Periodontology, Aichi-Gakuin University School of Dentistry \\ 2-11, Suemori-dori, Chikusa-ku, Nagoya 464-8651, Japan \\ E-mail kurosu@kurosu-dc.com
}


energy X-ray absorptiometry. The years since menopause in group O 2 were significantly longer than those in group $\mathrm{N}(P<0.05)$. No difference was found in the physical and smoking status of each group. The number of teeth present and any periodontal parameters, including probing depth, probing attachment level, bleeding on probing and alveolar bone loss, did not differ among 3 groups. The mandibular trabecular BMD (MTBMD) in groups $\mathrm{O} 1$ and $\mathrm{O} 2$ were significantly lower than those in group $\mathrm{N}(P<0.05)$. These results indicate that systemic BMD loss is seemed to be related to the risk of mandibular bone loss and MTBMD loss may be a predictor for postmenopausal women with increased risk of osteopenia/osteoporosis. J Jpn Soc Periodontol, 46:202-208, 2004.

Key words : quantitative computed tomography (QCT), mandible, bone mineral density (BMD), osteoporosis, periodontal disease

要旨： 骨粗鬆症は，骨量の減少を特徴とする疾患である。歯周病は，歯周組織の炎症により，歯槽骨吸収を 引き起こす。そこで，歯周病と骨粗鬆症との関係を把握する一助として，下顎骨骨密度 (BMD of mandible, M-BMD) と腰椎骨密度 (bone mineral density of lumbar spine，L-BMD）との関係について検討した。被験 者は，本研究の主旨に同意の得られた閉経後女性 30 名で，L-BMD から，2000 年度日本骨代謝学会の診断基準

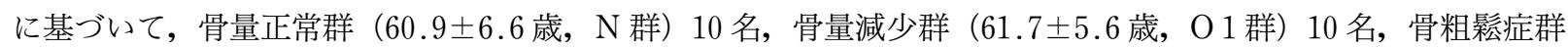
(66.6 77.0 歳, $\mathrm{O} 2$ 群) 10 名の 3 群に区分した。M-BMD は, 定量的コンピューター断層撮影 (quantitative computed tomography, QCT) 法, L-BMD は，二重エネルギーX 線吸収測定法 (dual energy X-ray absorptiometry, DEXA 法) を用いて測定した。閉経後年数は, $\mathrm{N}$ 群に比べ $\mathrm{O} 2$ 群が長かったが, その他の身体所 見や喫煙状態に差異はなかった。また, 現在歯数と歯周病所見（probing depth, probing attachment level, 歯 肉出血率，歯槽骨吸収率）は各群間ほぼ同じであったが，下顎骨海綿骨領域骨密度（mandibular trabecular BMD，MTBMD）は，N 群に比べ O 1 群と O 2 群が低下していた $(P<0.05)$ 。したがって，下顎骨は，全身 の BMD を反映しており，MTBMD の判定は，閉経後女性の骨減少症や骨粗鬆症双方のリスクを予知する可能 性が示唆された。

索引用語：定量的コンピューター断層撮影法，下顎骨，骨密度，骨粗鬆症，歯周病

\section{緒 言}

骨粗鬆症は，骨折リスクを増すような骨強度上の問 題をもつ人に起こる骨格の疾患と定義されている11。 近年の高齢化社会到来に伴い, 各年代の推定人口から 算出した 40 歳以上女性の骨粗鬆症域人口は，2000 年 783 万人から 2001 年 819 万人へと急激な増加が推定 されている ${ }^{2,3)}$ 。一方, 歯周炎は, 細菌感染などに起 因する歯槽骨吸収を特徵とするため, 骨粗鬆症に起因 する全身の骨量減少と，歯周炎にみられる局所の歯槽 骨吸収との関係に関心がもたれ，その因果関係を解明 すべく数久の研究が報告されている4 20)。これまで 我々は, 骨粗鬆症と歯周病との関係を把握する一助と して，まず，骨粗鬆症患者の歯周病態を調查し，骨粗 鬆症患者は対照群に比べ歯肉出血率 (bleeding on probing, BOP) が高く, 歯周病が進行傾向にあると 報告した4)。次に，閉経後成人女性歯周病患者の歯周 病態を調查し, 腰椎骨萎縮が進行しているほど歯槽骨 吸収が高度で，BOP が高いと報告してきた ${ }^{5 \sim 8)}$ 。さら
に，卵巣摘出による続発性骨粗鬆症が疑われた歯周病 患者では, 歯周炎が進行する可能性があることを報告 した9)。しかし，全身の骨密度 (bone mineral density，BMD）と局所の骨吸収の指標である歯槽骨吸 収 (alveolar bone loss, ABL) との関連性はこれま で認められていない。下顎骨や歯槽骨を評価した従来 の報告でも, 全身と局所の BMD の関係を肯定する報

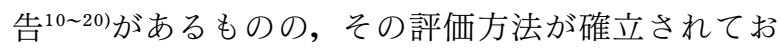
らず，全身 BMD と局所の BMD との関係は未だ明確 なコンセンサスが得られていない。また，近年では， $\mathrm{BMD}$ 測定法の中で最も精度の高い CT を用いる報告 が増加している。そこで, 本研究では, 定量的コン ピューター断層撮影 (quantitative computed tomography, QCT) 法を用いて, 下顎骨 BMD (BMD of mandible, M-BMD) を測定し, 二重エネルギーX 線吸収測定法 (dual energy X-ray absorptiometry, DEXA 法) にて測定した第 2〜第 4 腰椎 BMD (BMD of lumbar spine, L-BMD) との関係を評価 した。 


\section{被験者および方法}

本研究は, 愛知学院大学歯学部倫理委員会の承認 (平成 13 年 11 月 7 日承認) のもとに行われた。

\section{1. 被験者}

被験者は, 愛知学院大学歯学部附属病院歯周病科に 通院中の慢性歯周炎患者で, 本研究の主旨に同意の得 られた閉経後女性 30 名である。L-BMD は，はちゃ 整形外科病院（名古屋市）にて DEXA 法を用いた BMD 測定装置（ノーランド社製 XR 36 型，USA） により測定した。なお, L-BMD 測定は, 被験者の歯 周炎の程度を知らされていない測定者が行い，2000 年度日本骨代謝学会の原発性骨粗鬆症の診断基準 ${ }^{21)}$ に 従い, 以下の 3 群に区分した。すなわち, L-BMD が 若年成人平均値 (young adult mean, YAM) の $80 \%$ 值以上の骨量正常群（ $\mathrm{N}$ 群）10 名（60.9 06.6 歳), 同診断が $70 \%$ 值以上 $80 \%$ 值未満の骨量減少群 (O 1 群) 10 名 (61.7 55.6 歳), 同診断が $70 \%$ 值未 満の骨粗鬆症群 (O 2 群) 10 名（66.6 7 7.0 歳）であ る。なお， L-BMD 測定と M-BMD 測定の期間は, 平均 $0.7 \pm 1.4$ 年であった。

\section{2. 臨床パラメーター}

1) 全身所見
(1) 身長
(2) 体重
(3) 体格指数 (body mass index, BMI)
(4) 閉経年歯, 閉経後年数
（5）喫煙習慣

2）口腔内所見

(1) 現在歯数

(2) probing depth (PD)

(3) probing attachment level (PAL)

(4) $\mathrm{BOP}$

(5) $\mathrm{ABL}$

(6) $\mathrm{M}-\mathrm{BMD}$

a ) 下顎骨皮質骨領域 BMD (mandibular cortical BMD, MCBMD)

b ) 下顎骨海綿骨領域 BMD (mandibular trabecular BMD, MTBMD)

現在歯数を除く口腔内所見は，下顎を評価した。口 腔内診查は，すべて L-BMD の状態を知らされてい ない 1 名の術者が行った。PD と PAL は, $15 \mathrm{~mm} の$ 歯周プローブ (CPUNC 15, Hu-Friedy, USA) を 用いて, 6 点法, $1 \mathrm{~mm}$ 単位で測定した。なお, ABL は, Schei らの方法 ${ }^{22)} に$ 準じ，被検歯の近遠心を計測 した。M-BMD は, 同病院歯科放射線科の CT

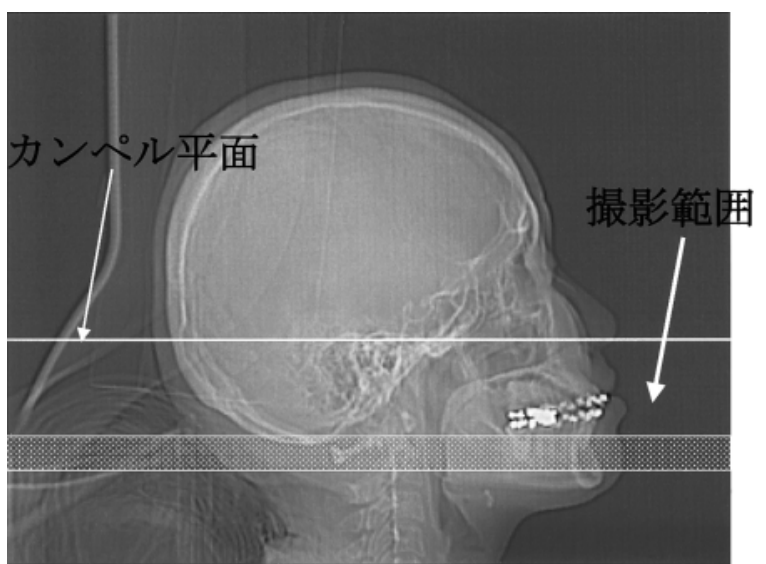

図 1 撮影範囲

(HiSpeedNX/i Pro，GE，東京）を用いた QCT 法 により測定した。

\section{CT の撮影条件と画像処理}

撮影条件は，ヘリカルスキャンで管電圧 $120 \mathrm{kV}$, 管電流 $200 \mathrm{~mA}$ とした。撮影時には, 頭部を専用のイ ヤーロッドにて固定し，5段階に設定したハイドロキ シアパタイトファントム（0～ $\left.400 \mathrm{mg} / \mathrm{cm}^{3} \mathrm{HA}\right)$ を下 顎右側第一小臼歯歯根相当部の口腔外に貼付し，同時 撮影した。頭部の前後的傾斜は, ガイドビームをカン ペル平面に平行になるように設定した（頭部はカンペ ル平面が床面と直角となるように設定した）。また， 被験者に対する被曝線量を最小限に抑えるため, 撮影 する範囲は，オトガイ孔から下顎歯槽頂の間に限定し た（図 1)。断層面は，1.0 mm 幅で構築し，その中 から左右オトガイ孔を含む画像を抽出し, M-BMD の計測を行った。

CT 画像は, DICOM 形式で医用画像表示システム (VOX-BASE ${ }^{\circledR}, \mathrm{J}-\mathrm{Mac}$ System，札幌）を介して パーソナルコンピュータ (Macintosh PowerBook G 4, Apple Computer Inc, USA) に取り込み, 解 析には, 画像解析ソフトウェア (NIH image ver 1.62, National Institute of Health，USA）を用 いて BMD の算出を行った。まず，下顎骨の皮質骨領 域と海綿骨領域の境界を設定するために，あらかじめ 用意しておいた BMD の正常な下顎骨 CT 画像 5 枚を 用い，抽出範囲として明らかに皮質骨が抽出されてい ると思われる画素值（ピクセル值）の平均值を計測し た。この操作は, すべて L-BMD の状態を知らされ ていない, 口腔内診査を行った術者とは別の 1 人の測 定者が行った。この画素值（ピクセル值）の平均值を 下顎骨の皮質骨領域と海綿骨領域の境界の值とした。 ここで示した画素值（ピクセル值）は 12 ビットであ り, CT 值 (HU) と同等であるため, 以後画素值を 


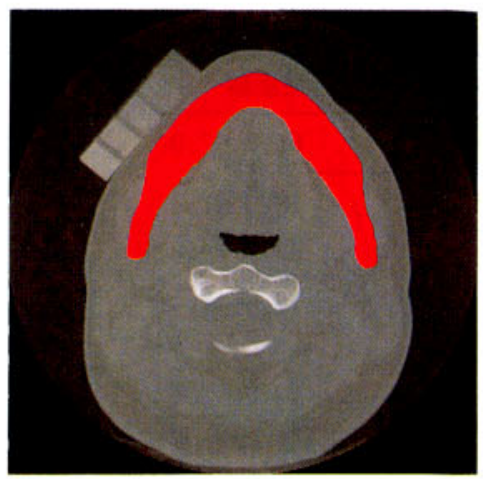

下䫟骨全体

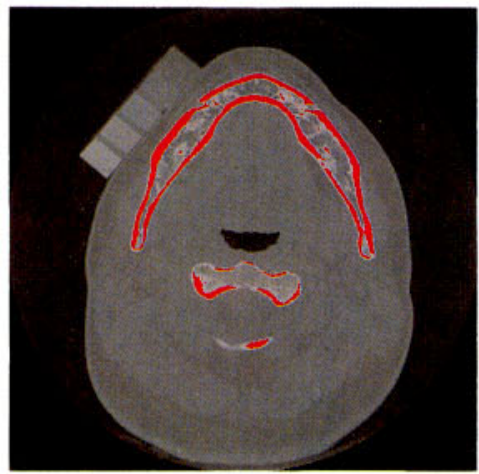

皮質骨領域

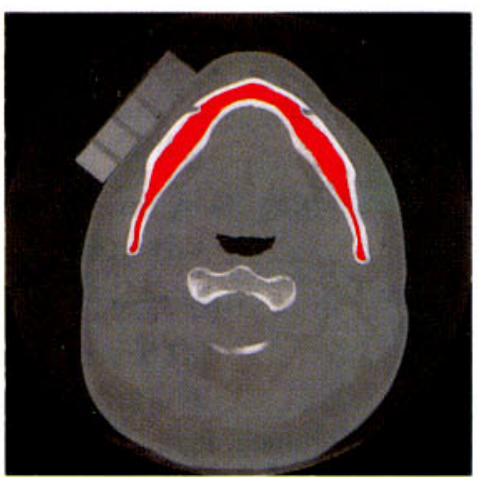

海綿骨領域

図 2 皮質骨領域と海綿骨領域

CT 值と呼ぶこととし，それぞれのCT 值を算出した (図 2)。その後, 撮影時に貼付したハイドロキシアパ タイトファントムにより求めた近似直線から, MCBMD とMTBMD を算出した（MCBMD は外扦 値)。なお, 統計処理は, 各群間の比較には一元配置 分散分析を用いた（SPSS 11.0 J for windows）。

\section{結＼cjkstart果}

\section{1. 全身的所見}

BMI, 閉経年齢, 閉経後年数は, それぞれ $\mathrm{N}$ 群 $23.5 \pm 3.1,51.5 \pm 3.7$ 歳, $9.7 \pm 6.3$ 年, O 1 群 $20.7 \pm 2.8,49.7 \pm 3.4$ 歳, $12.2 \pm 7.5$ 年, O 2 群 $19.9 \pm 2.4,49.7 \pm 3.5$ 歳, $16.9 \pm 7.1$ 年であった。閉 経年㱓は, 各群ほぼ同一であったが，N 群に比べ, $\mathrm{O} 2$ 群は年歯と BMI が高く, 閉経後年数が長かった $(P<0.05$, 表 1)。喫煙者は, O 2 群 1 名だけです た。L-BMDとYAM は, それぞれ N 群 $0.961 \pm$ $0.064 \mathrm{~g} / \mathrm{cm}^{2}, 92.1 \pm 4.3 \%$, O 1 群 $0.788 \pm 0.036 \mathrm{~g} /$ $\mathrm{cm}^{2}, 74.0 \pm 3.4 \%$, O 2 群 $0.682 \pm 0.060 \mathrm{~g} / \mathrm{cm}^{2}$, $64.0 \pm 5.7 \%$ であった（表 2$) 。$

\section{2. 口腔内所見}

現在歯数は, $\mathrm{N}$ 群 $23.6 \pm 5.2$ 歯, O 1 群 $25.4 \pm 0.4$ 歯, O 2 群 $24.6 \pm 2.3$ 歯で, 各群ほほ同一であった。

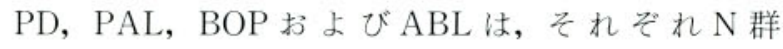
$2.9 \pm 0.5 \mathrm{~mm}, 4.0 \pm 1.1 \mathrm{~mm}, 35.6 \pm 17.1 \%$, $26.0 \pm 10.4 \%$, O 1 群 $2.9 \pm 0.7 \mathrm{~mm}, 4.2 \pm 1.2$ $\mathrm{mm}, 41.4 \pm 18.8 \%, 31.4 \pm 11.8 \%$ ，O 2 群 $2.7 \pm 0.4$ $\mathrm{mm}, 4.1 \pm 1.1 \mathrm{~mm}, 37.4 \pm 16.0 \%, 29.0 \pm 12.3 \%$ で，各群間に差異はみられず，歯周炎は，各群同程度 であった（表 1)。MCBMD とMTBMDは，それぞ れ $\mathrm{N}$ 群 $1125.8 \pm 40.2 \mathrm{mg} / \mathrm{cm}^{3} \mathrm{HA}, 364.8 \pm 86.2 \mathrm{mg} /$ $\mathrm{cm}^{3} \mathrm{HA}$, O 1 群 $1102.4 \pm 38.0 \mathrm{mg} / \mathrm{cm}^{3} \mathrm{HA}, 300.7 \pm$
$54.8 \mathrm{mg} / \mathrm{cm}^{3} \mathrm{HA}$, O 2 群 $1101.8 \pm 38.2 \mathrm{mg} / \mathrm{cm}^{3}$ HA, $287.2 \pm 51.0 \mathrm{mg} / \mathrm{cm}^{3} \mathrm{HA}$ であった。MCBMD に差異はみられなかったが，O 2 群の MTBMD は, $\mathrm{N}$ 群に比べ低下していた $(P<0.05$, 表 2$)$ 。また, L-BMD とMTBMD は, 相関傾向 $(r=0.341, P=$ 0.065 )を示した。

\section{考察}

全身の BMD が低下する骨粗鬆症患者では, 局所で ある下顎骨や歯槽骨部の BMD も低下している可能性 がある。上頭骨も同様に，BMD が低下していると考 えられるが，全身の BMD と M-BMD 調査した報 告 ${ }^{(0,11,14 \sim 18)}$ に比へ，上顩骨の BMD を調査した報告 ${ }^{19)}$ は少ない。すなわち, 上顎骨は形態が複雑で, 上顎骨 BMD 走確に評価する測定法が確立されておらず， BMD 測定が困難であるからである ${ }^{23)}$ 。そこで, 本研 究では, 下顎骨を皮質骨領域と海綿骨領域に分けて M-BMD を評価した。その結果, L-BMD と海綿骨 領域を示唆するMTBMDの間に相関傾向を認めた。 すなわち, 骨粗鬆症による BMD 低下は, 主に海綿骨 で顕著である ${ }^{24)}$ ためであると思われる。

一方，皮質骨領域を示唆する MCBMD に相関が認

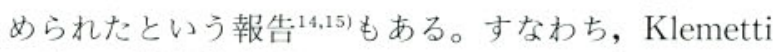
ら ${ }^{14)}$ は, 閉経後女性の M-BMD をQCT 法を用いて 測定し, 腰椎 BMD, 大腿骨頸部 BMD と下顎骨皮質 骨領域 BMDの間に相関が認められた（腰椎 $r=$ 0.51 , 大腿骨頸部 $\mathrm{r}=0.59, P<0.05)$ と報告してい る。次に, Taguchi ら ${ }^{15)}$ は, 二重エネルギーコン ピューター断層撮影 (dual-energy quantitative computed tomography, DEQCT) 法を用い, MBMD と第 3 腰椎の L-BMD を測定した。その結果, 閉経後 5 年未満の群で, 下澦骨皮質骨 BMD と第 3 腰 
表 1 背景因子と口腔内所見

\begin{tabular}{cccc}
\hline & 骨量正常群 $(\mathrm{n}=10)$ & 骨量減少群 $(\mathrm{n}=10)$ & 骨粗鬆症群 $(\mathrm{n}=10)$ \\
\hline 年齢 & $60.9 \pm 6.6$ & $61.7 \pm 5.6$ & $66.6 \pm 7.0$ \\
体格指数 (body mass index BMI) & $23.5 \pm 3.1$ & $20.7 \pm 2.8$ & $19.9 \pm 2.4$ \\
閉経年歯 & $51.5 \pm 3.7$ & $49.7 \pm 3.4$ & $49.7 \pm 3.5$ \\
閉経後年数 & $9.7 \pm 6.3$ & $12.2 \pm 7.5$ & $16.9 \pm 7.1$ \\
喫煙経験者 & 0 & 0 & 1 \\
現在歯数 & $23.6 \pm 5.2$ & $25.4 \pm 0.4$ & $24.6 \pm 2.3$ \\
probing depth (PD) (mm) & $2.9 \pm 0.5$ & $2.9 \pm 0.7$ & $2.7 \pm 0.4$ \\
probing attachment level (PAL) & $4.0 \pm 1.1$ & $4.2 \pm 1.2$ & $4.1 \pm 1.1$ \\
$(\mathrm{~mm})^{\mathrm{a}}$ & $35.6 \pm 17.1$ & $41.4 \pm 18.8$ & $37.4 \pm 16.0$ \\
歯肉出血率 $(\mathrm{BOP})(\%)^{\mathrm{a}}$ & $26.0 \pm 10.4$ & $31.4 \pm 11.8$ & $29.0 \pm 12.3$ \\
歯槽骨吸収率 $(\mathrm{ABL})(\%)^{\mathrm{a}}$ & &
\end{tabular}

平均土標準偏差

$*: P<0.05$, ANOVA

BMI と閉経後年数補正後, 口腔内所見を比較したが, 有意差はみられなかった。

a下顎だけの平均

表 2 骨密度

\begin{tabular}{cccc}
\hline & $\begin{array}{c}\text { 骨量正常群 }(\mathrm{n}=10) \\
\text { (YAM } 92.1 \pm 4.3 \%)\end{array}$ & $\begin{array}{c}\text { 骨量減少群 }(\mathrm{n}=10) \\
\text { (YAM } 74.0 \pm 3.4 \%)\end{array}$ & $\begin{array}{c}\text { 骨粗鬆症群 }(\mathrm{n}=10) \\
\text { (YAM } 64.0 \pm 5.7 \%)\end{array}$ \\
\hline $\begin{array}{c}\text { 腰椎骨密度 }(\mathrm{L}-\mathrm{BMD}) \\
\left(\mathrm{g} / \mathrm{cm}^{2}\right)\end{array}$ & $0.961 \pm 0.064$ & $0.788 \pm 0.037$ & $0.682 \pm 0.060$ \\
$\begin{array}{c}\text { 下顎骨皮質骨領域骨密度 } \\
(\mathrm{MCBMD})\left(\mathrm{mg} / \mathrm{cm}^{3} \mathrm{HA}\right)\end{array}$ & $1125.8 \pm 40.2$ & $1102.4 \pm 38.0$ & $1101.8 \pm 38.2$ \\
$\begin{array}{c}\text { 下顎骨海綿骨領域骨密度 } \\
(\mathrm{MTBMD})\left(\mathrm{mg} / \mathrm{cm}^{3} \mathrm{HA}\right)\end{array}$ & $364.8 \pm 86.2$ & $300.7 \pm 54.8$ & $287.2 \pm 51.0$ \\
\hline
\end{tabular}

平均土標準偏差

YAM（腰椎骨密度の若年成人平均值に対する比率）

$*: P<0.05$, ANOVA.

椎 BMD（腰椎皮質骨 $\mathrm{r}=0.73$, 腰椎海綿骨 $\mathrm{r}=0.66$, $P<0.05)$ ，閉経後 5 年以上の群で，下顎骨皮質骨 BMD，下顎骨海綿骨 BMD と第 3 腰椎海綿骨 BMD (下顎骨皮質骨 $\mathrm{r}=0.46$, 下顎骨海綿骨 $\mathrm{r}=0.41, P<$ 0.01）に有意な相関を報告している。さらに，板東 ら ${ }^{16)}$ は，QCT 法を用いて M-BMD を測定し，無歯顎 者の下顎骨皮質骨領域 BMD は，有歯顎者に比べ有意 に低く，無歯顎者の下顎骨皮質骨領域 BMD と L$\mathrm{BMD}$ との間の相関 $(\mathrm{r}=0.77)$ を報告している。し かし，両報告とも歯周病所見などの BMD に影響を及 ぼす可能性のある局所因子は評価していない。本研究 では，被験者のほとんどが急激に BMD が低下する時 期を過ぎた閉経後 5 年以上経過した時期で, およそ 24 歯以上の多くの歯が残存し，その歯周病所見に差
異がみられないことを確認した上で，全身骨の指標で ある腰椎と下顎骨の BMD を検討した。その結果, L-BMD と皮質骨領域を示唆する MCBMD には関連 を認めなかったが，L-BMD と海綿骨領域を示唆する MTBMD の間に相関傾向を認めた。MCBMD が外挿 值であるため, 前述の研究と正確な比較はできないも のの, L-BMD の減少した骨粗鬆症群で, MTBMD の有意な低下を確認した点は, 従来の報告にはない包 括的な研究である。

一方，本研究では，M-BMD を測定したが，歯周 炎の影響を直接受けるのは歯槽骨である。そのため, 歯槽骨 BMD (BMD of alveolar bone, A-BMD) も 同時に測定していく必要性がある。しかし, 歯槽骨 は, 歯周病以外にも他の局所因子の影響を受け，A- 
BMD を正確に測定することが困難であった。Southard ${ }^{19)}$ は，A-BMD を測定するため，臼歯部の歯科 用 X 線写真，バイトウイングを撮影する際，6段階 のアルミニウムステップウェッジを同時撮影し，その 濃度から A-BMD を換算し，上顎の A-BMD と下顎 の A-BMD, 腰椎 $(\mathrm{r}=0.57, \mathrm{r}=0.53, P<0.01)$, 橈骨, 大腿骨 BMD $(r=0.39, r=0.39, P<0.001)$ との間の相関を報告している。しかし，この評価法 は, 歯槽骨の煩舌的幅経による誤差が生じる可能性が あり，A-BMD を正確に評価することは困難である。 本研究では, QCT の撮影範囲をオトガイ孔を含むと 予想される断層面付近から下顎骨歯槽頂部を含む範囲 に限定し，下顎骨だけでなく歯槽骨も測定可能とな り，かつ，被験者に対する被曝線量を最小限に抑える ための撮影範囲であることから，適応範囲の広い評価 法である。さらに, QCT は, 測定精度が高く, BMD の評価に用いられてきており ${ }^{14 \sim 16)}$ ，インプラント手 術の診断にも用いられていることから，本法をうまく 応用すれば，同時に M-BMD の評価も可能となり， インプラント手術の適否や予知性の把握にも今後幅広 く有用となると思われる。

本研究により，下顎骨は，全身の BMD を反映し， M-BMD の評価は, 骨粗鬆症の重要な指標となる可 能性が示唆された。今後, A-BMDについても, BMD に影響を与える因子について十分に考慮した上 で検討を重ねていく予定である。

\section{謝 辞}

今回の研究にご協力，ご指導いただいた本学歯科放射線 学講座泉雅浩助教授, 同放射線科技師長奥村信次先生, は ちや整形外科病院院長蜂谷裕道先生，同放射線科技師井澤 浩之先生, 矢野博康先生に深く感謝いたします。

本研究の一部は, 平成 16 年度科学研究費補助金（基盤 研究 (B) 一般 1 課題番号 16390616）の補助によって行わ れ, 第 61 回愛知学院大学歯学会 (2002 年 12 月 7 日, 名 古屋), 第 46 回秋季日本歯周病学会学術大会 (2003 年 10 月 18 日，新潟）に扔いて発表した。

\section{参考文献}

1) NIH Consensus Development Panel on Osteoporosis Prevention, Diagnosis, and Therapy. JAMA, 285(6) : 785-795, 2001.

2) 山本逸雄: 骨粗鬆症人口の推定. Osteoporosis Jpn, $7: 10-11,1999$.

3）福永仁夫：骨粗鬆症 罹患率の推定. Osteoporosis Jpn, 10：11-13, 2002.

4）稲垣幸司，大島康成，鈴木秀人，藤城治義，柳楽た
まき，吉成伸夫，橋本雅範，瀧川 融，小澤 晃， 野口俊英 : 骨粗鬆症患者の歯周病罹患状況. 日歯周 誌, $38 ： 220-225,1996$.

5) Inagaki $K$, Fujishiro $H$, Ohshima $Y$, Suzuki $H$, Asai Y, Nagira T, Murase M, Yoshinari N, Poblete MGS, Noguchi T, Kumazaki E, Nagao T, Mori C, Hayakawa J, Yamada K, Hachiya H : Periodontal and osteoporotic conditions in postmenopausal women. Aichi-Gakuin Dent Sci, 9 : 33-40, 1996.

6）藤城治義，大島康成，浅井勇吾，川瀬仁史，柳楽た まき, Marie Grace S. Poblete, 吉成伸夫，稲垣 幸司，野口俊英：歯周病を主訴とした閉経後成人女 性の骨粗鬆症所見と歯周病態との関係. 日歯周誌, $39: 226-233,1997$.

7）大島康成，藤城治義，浅井勇吾，川瀬仁史，柳楽た まき，吉成伸夫，稲垣幸司，野口俊英，長尾智子， 熊崎映子, 早川純子, 山田和代，蜂谷裕道：閉経後 成人歯周病患者の骨粗鬆症所見. 愛院大歯誌, 35 ： 449-454, 1997.

8）黑須康成，神谷武秀，川瀬仁史，近藤富貴子，藤城 治義, Vivian Lao Ti，柳楽たまき，宮下朋久， 澤 政樹, 吉成伸夫，稲垣幸司，野口俊英：閉経後 成人女性歯周病患者の歯周病所見と骨粗鬆症所見. 日歯保存誌, 41：952-960, 1998.

9）神谷武秀，近藤富貴子，黒須康成，柳楽たまき，山 本茂実，宮下朋久，澤 政樹，吉成伸夫，稲垣幸 司，野口俊英：卵巣摘出に伴う続発性骨粗鬆症と歯 周病の関係. 日歯保存誌, 42：594-601, 1999.

10) Kribbs PJ, Smith DE, Chesnut CH, 3 rd : Oral findings in osteoporosis. Part II : Relationship between residual ridge and alveolar bone resorption and generalized skeletal osteopenia. J Prosthet Dent, $50: 719-724,1983$.

11) Jacobs R, Ghyselen J, Koninckx P, van Steenberghe $\mathrm{D}$ : Long-term bone mass evaluation of mandible and lumbar spine in a group of women receiving hormone replacement therapy. Eur J Oral Sci, $104:$ 10-16, 1996.

12) Streckfus CF, Johnson RB, Nick T, Tsao A, Tucci M : Comparison of alveolar bone loss, alveolar bone density and second metacarpal bone density, salivary and gingival crevicular fluid interleukin-6 concentrations in healthy premenopausal and postmenopausal women on estrogen therapy. J Gerontol A Biol Sci Med Sci, 52 : 343351, 1997.

13) Shrout MK, Hildebolt CF, Potter BJ, Brunsden TKB, Pilgram TK, Dotson M, Yokoyama-Crothers N, Hauser J, Cohen S, Kardaris E, Civitelli R, Hanes P : Comparison of morphological measurements extracted from digitized dental radio- 
graphs with lumbar and femoral bone mineral density measurements in postmenopausal women. J Periodontol, $71: 335-340,2000$.

14) Klemetti E, Vainio P, Lassila V, Alhava E : Cortical bone mineral density in the mandible and osteoporosis status in postmenopausal women. Scand J Dental Res, $101: 219-223,1994$.

15) Taguchi A, Tanimoto K, Suei $Y$, Ohama K, Wada $\mathrm{T}$ : Relationship between the mandibular and lumbar vertebral bone mineral density at defferent postmenopausal stages. Dentomaxillofac Radiol, 25 : 130-135, 1996.

16）板東 薰，新田 浩，笹生宗賢，野口和行，誉田栄 一，植松 宏，石川 烈：閉経後女性の有歯顎者と 無歯顎者における腰椎骨密度と下顎骨骨密度につい て. 日歯周誌, $42: 122-28,2000$.

17) von Wowern N, Klausen B, Kollerup G : Osteoporosis: A risk factor in periodontal disease. J Periodontol, 65 : 1134-1138, 1994.

18) von Wowern N, Storm TL, Olgaard K : Bone mineral content by photon absorptiometry of the mandible compared with that of the forearn and the lumbar spine. Calcif Tissue Int, $42: 157-161$, 1998.

19) Southard KA, Southard TE, Schlechte JA, Meis PA : The relationship between the density of the alveolar processes and that of post-cranial bone. J Dent Res, 79 : 964-969, 2000.

20) Geurs NC, Lewis CE, Jeffcoat MK : Osteoporosis and periodontal disease progression. Periodontol 2000, $32: 105-110,2003$.

21）折茂 肇：原発性骨粗鬆症の診断基準. Osteoporosis Jpn, 9:9-14, 2001

22) Schei O, Waerhaug J, Lovdal A, Arno A : Alveolar bone mass as related to oral hygiene and age. J Periodontol, 30:7-16, 1959.

23) Sanfilippo F, Bianchi AE : Osteoporosis : The effect on maxillary bone resorption and therapeutic possibilities by means of implant prosthesesa literature review and clinical considerations. Int J Perio Rest Dent, 23：47-457, 2003.

24）折茂 肇：骨粗鬆症の分類と鑑別診断，松本俊夫, プラクティカル内科シリーズ 4 骨粗鬆症, 南江 堂, 東京, 1998. 